\title{
DUST EXPOSURE TO THE LUNG FUNCTION CAPACITY OF LIMESTONE INDUSTRY WORKERS IN WEST BANDUNG REGENCY
}

\author{
Suherdin $^{1}$, Krisna Dwi Mulya ${ }^{2}$, Ratna Dian Kurniawati ${ }^{3}$ \\ ${ }^{1}$ Department of Occupational Health and Safety, Faculty of Public Health, Airlangga University \\ ${ }^{2,3}$ Department of Public Health, Faculty of Health Sciences, Bhakti Kencana University
}

\begin{abstract}
According to the International Labor Organization (ILO) data in 2013,30\% to 50\% of workers in developing countries suffer from pneumoconiosis. Besides, the ILO detected that around 40,000 new cases of pneumoconiosis (respiratory disease) caused by workplace dust exposure occur throughout the world each year. The purpose of this study was to determine the relationship of limestone dust exposure to lung function capacity in the limestone processing industry workers. This type of research is an observational descriptive using a cross-sectional approach. The population is 166 workers from 3 limestone companies in the area of the Cipatat Health Center, West Bandung Regency, 150 workers of PT. Batu Wangi, 8 workers from PT. Tunas Putra, and 8 workers from PT. BP. The sampling technique uses stratified sampling. The number of samples was 32 workers. Data analysis to look for relationships between variables using the Chi-Square formula. The results of the study were $56.2 \%$ of workers had normal lung function capacity, and $43.8 \%$ of workers had abnormal lung function capacity. There are 66.7\% of companies having dust exposure levels according to $T L V$, and 33.3\% exceeding TLV. Chi-square Analysis Results, p-value =1,000 (>0.05), so that there is no relationship between lime dust exposure and lung function capacity. The conclusion of the study, there is no relationship between limestone dust exposure and lung function capacity in the limestone processing industry workers.
\end{abstract}

Keywords: Dust exposure, limestone, lung capacity

\section{PAPARAN DEBU BATU KAPUR TERHADAP KAPASITAS FUNGSI PARU PEKERJA INDUSTRI BATU KAPUR KABUPATEN BANDUNG BARAT}

\begin{abstract}
ABSTRAK
Menurut International Labour Organization (ILO) tahun 2013, 30\% hingga 50\% pekerja di negara berkembang menderita pneumokoniosis. Selain itu, ILO mendeteksi bahwa sekitar 40.000 kasus baru pneumokoniosis (penyakit saluran pernafasan) yang disebabkan oleh paparan debu tempat kerja terjadi di seluruh dunia setiap tahunnya. Tujuan penelitian ini untuk mengetahui hubungan paparan debu batu kapur terhadap kapasitas fungsi paru pada pekerja industri pengolahan batu kapur. Jenis penelitian ini adalah observasional deskriptif dengan menggunakan pendekatan cross sectional. Populasi sebanyak 166 orang pekerja dari 3 perusahaan batu kapur di area Pusat Kesehatan Masyarakat Cipatat, Kabupaten Bandung Barat, 150 pekerja PT. Batu Wangi, 8 pekerja PT. Tunas Putra, dan 8 pekerja dari PT. BP. Tekhnik pengambilan sampel menggunakan stratified sampling. Jumlah sampel 32 orang pekeerja. Analisis data untuk mencari hubungan antar variabel menggunakan rumus chi-square. Hasil penelitian didapatkan $56.2 \%$ pekerja mempunyai kapasitas fungsi paru normal dan $43.8 \%$ pekerja mempunyai kapasitas fungsi paru tidak normal. Terdapat $66.7 \%$ perusahaan pengolahan batu kapur dengan kadar paparan debu sesuai NAB, dan $33.3 \%$ memiliki kadar paparan debu melebihi NAB. Hasil Analisis chi-square, $p$-value $=1.000(>0.05)$, tidak ada hubungan antara paparan debu batu kapur dengan kapasitas fungsi paru pada pekerja industri pengolahan batu kapur.
\end{abstract}

Kata Kunci: Pajanan debu, batu kapur, kapasitas paru

Correspondece Address: Ratna Dian Kurniawati, Department of Public Health, Faculty of Health Sciences, Bhakti Kencana University, Email: ratna.dian@bku.ac.id 


\section{INTRODUCTION}

Occupational Safety and Health (OSH) is one aspect of labor protection while protecting company assets. This is reflected in the points of thought and consideration of the issuance of President of the Republic of Indonesia, 1970 about work safety Article 1 namely that every worker has the right to get protection for safety in doing work and every other person in the workplace needs to be guaranteed his safety and every source of production needs to be used and used efficiently so that the production process runs smoothly. ${ }^{1}$

Safeguards for workers against the dangers that arise are basic needs. Harmony in work, which means that guaranteed occupational safety and health and work productivity as high as possible, this is influenced by workload, work environment and work capacity. ${ }^{2}$

The work environment is the overall tools and materials faced, the surrounding environment in which a person works, his work methods, and his work arrangements both as individuals and as a group. The type of work environment is divided into physical and nonphysical work environments. The physical work environment including dust. ${ }^{3}$

Dust is solid particles that are caused by natural or mechanical forces such as processing, crushing, softening, rapid packing, detonation, and others from organic or inorganic materials. Like limestone processing, in addition to reducing the aesthetic value of the environment, dust from the lime industry process can also cause health problems, one of which is a decrease in lung function. ${ }^{4}$

Impaired lung function is a disorder or disease experienced by the lungs caused by various causes, such as viruses, bacteria, dust, and other particles. Respiratory diseases classified as spirometry tests are of two kinds, namely diseases that cause obstructive ventilation disorders and diseases that cause restrictive ventilation. ${ }^{5}$

Data from the National Institute for Occupational Safety and Health (NIOSH) in the United States of America that respiratory diseases are the first of the top ten occupational diseases, it is estimated that the death rate related to occupational lung disease is around $70 \%$ of total deaths due to work. According to the Center for Disease Control and Prevention (CDC), $30 \%$ of people with Chronic Obstructive Pulmonary Disease (COPD) and adult asthma sufferers are caused by workplace exposures. ${ }^{6,7}$

Based on data from the International Labour Organization (ILO), among all occupational diseases, $30 \%$ to $50 \%$ are silicosis and other pneumoconiosis diseases. Besides, the International Labor Organization (ILO) detected that around 40,000 new cases of pneumoconiosis (respiratory disease) caused by workplace dust exposure occur throughout the world each year. ${ }^{8}$

In Indonesia, dust or illness due to work caused by dust is estimated to be quite a lot, although the available data is still lacking. The results of lung capacity checks conducted at the South Sulawesi Center for Health and Occupational Health in 1999 of 200 workers in 8 companies, obtained results of $45 \%$ of respondents experiencing restrictive pain, $1 \%$ of respondents experiencing obstructive and $1 \%$ of respondents experiencing Combination (combined between restrictive and obstructive). The results of the examination of the lung function capacity of limestone burning workers in Karangdawa Village by the Tegal District Health Office in 2006, as many as 102 people $(49.76 \%)$ were not normal lung capacity. ${ }^{9}$

Measurement of lung function capacity is one way to find out the initial symptoms of decreased lung function that can lead to Acute Respiratory Infection (ARI). Data from the Cipatat Health Center in West Bandung Regency, which houses the limestone processing industry, shows that ARI is in the 
top 10 diseases and ranks first in 1120 cases, $60 \%$ (672 cases) of which are limestone processing workers or in limestone mining. One of the factors that influence ARI is air pollution. ${ }^{10}$

The phenomenon that occurs in the limestone processing plant is the number of workers' complaints about health problems experienced by workers in the factory area, namely breathing becomes congested, often catching the flu, sore eyes, dizziness, and skin disorders.

Based on preliminary observations, researchers obtained information about the working conditions of the limestone processing plant in general, located in the area of Cipatat Health Center, a factory that processes limestone into raw materials for making roofing, ceramics, cosmetics, animal feed, fertilizers, detergents as well as for iron smelting steel. The processing of the limestone results in a byproduct, namely limestone dust that flies around the factory even along the Cipatat Rajamandala road.

According to data from the West Bandung Regency Environmental Office in 2008, limestone mining in the area is a significant source of regional income. Nearly $80 \%$ of the population in the Padalarang, Batujajar, and Cipatat areas depend on their livelihoods for the mining and processing of limestone.

The working hours at the limestone processing plant averaged nearly 10 hours per shift, with work schedules divided into 2 shifts. The workers at the limestone processing plant do not use masks to protect themselves from exposure to lime dust.

Dust can cause lung damage and fibrosis if inhaled continuously during work. When the alveoli harden, consequently, it reduces elasticity in accommodating the volume of air so that the oxygen binding ability decreases. ${ }^{11}$

Decreased lung vital capacity is one of the symptoms of pulmonary function impairment if left continuously without any preventive action taken, and it can be a potential occupational disease such as pneumoconiosis and even lung cancer due to the accumulation of dust in the lungs. ${ }^{12}$

In connection with the above background, given the importance of occupational safety and health for workers, the authors are interested in researching the occurrence of Relationship Between Limestone Exposure to Lung Function Capacity in Lime Stone Industry Workers in the Cipatat Puskesmas Area in West Bandung Regency.

This study aims to determine the relationship between exposure to limestone dust with the capacity of the lung function in the limestone processing industry workers in the area of Cipatat Puskesmas, West Bandung Regency.

\section{METHOD}

This research uses a quantitative approach, a type of analytic observational study with a cross-sectional design. ${ }^{13,14}$

The variables in this study are divided into two variables. First, the independent variable is limestone dust exposure, and the dependent variable is the lung function capacity. The population in this study were all workers from 3 limestone companies in the area of Cipatat Health Center, West Bandung Regency, as many as 166 people, 150 workers from PT. Batu Wangi, 8 workers from PT. Tunas Putra, and 8 people from PT. "BP."

Sampling technique uses stratified sampling, the number of samples used as research subjects was 32 people, with each 28 representing the population at PT. Batu Wangi, 2 people, are representing CV. Tunas Putra and 2 people are representing $\mathrm{CV}$. "BP."

Subject selection was determined based on the following criteria: Inclusion criteria, wherein the researcher made this subject a sample, with criteria, male gender, no smoking, no history of asthma and other lung function disorders, productive age, willing be a research sample. Exclusion Criteria wherein the 
researcher did not make this subject into the sample, the exclusion subjects in this study included labor who were sick and resigned.

Data collection techniques used in this research is by measuring and studying documentation. Measurements were made to measure lime dust exposure using a Low Volume Dust Sample and to measure lung function capacity using a spirometer. Documentation study using secondary data to see data about respiratory problems or upper respiratory tract infections in the Health Center Cipatat area.
Data were analyzed univariately, wherein analyzing each variable in the form of a frequency distribution, bivariate on each variable to see if there was a relationship between the independent variable and the dependent variable using the chi-square statistical test. ${ }^{14}$ This research was declared ethical by the Health Research Ethics Commission of the Bhakti Kencana School of Health Bandung with the number 085/KMSBK/EC/VII/2014.

\section{RESULT}

Table 1.

Frequency Distribution of Limestone Exposure in the Limestone Processing Industry of Cipatat Health Center, West Bandung Regency

\begin{tabular}{ccc}
\hline Dust Exposure & \multicolumn{2}{c}{ Distribution } \\
\cline { 2 - 3 } Category & $\mathbf{n}$ & $\mathbf{( \% )}$ \\
\hline Conformance TLV & 2 & 66.7 \\
Non-conformance & 1 & 33.3 \\
TLV & 3 & 100.0 \\
Total & & \\
\hline
\end{tabular}

From table 1, of Limestone Dust Exposure in the Limestone Processing Industry of the Cipatat District Health Center in West Bandung Regency, it was found that

Limestone is a natural material that is widely available in Indonesia. Limestone is a solid rock that contains a lot of calcium carbonate. ${ }^{15}$ Some research explained that the carbonate mineral commonly found associated with limestone is aragonite $\left(\mathrm{CaCO}_{3}\right)$, which is a metastable mineral because at certain times it can turn into calcite $\left(\mathrm{CaCO}_{3}\right){ }^{15,9}$

Calcium carbonate is an inorganic mineral that is known to be available at commercially low prices. The physical properties of calcium carbonate such as morphology, phase, size and size distribution, must be modified according to their fields of application. The morphological shape and phase of calcium carbonate $\left(\mathrm{Ca}\left(\mathrm{CO}_{3}\right)\right.$ are related to synthesis conditions such as reactant the majority $(66.7 \%)$ of the limestone processing industry had conditions according to Threshold Limit Values.

concentration, temperature, aging time and natural addictive substances). ${ }^{15}$

Since it was discovered as a raw material that can be processed, the production of calcium oxide from rock stones is one of the oldest chemical transformations produced by humans. Its use precedes historical records.

The most ancient languages such as Latin calcium oxide are known as "calx", from which the name calcium element is taken. In ancient English, the name "lim," which is the origin of the common commercial name for calcium oxide, which is limestone. The abundance of limestone in the earth's crust and the ease of transformation into calcium oxide does not alone explain why lime is one of the 
oldest chemical products. Lime has many properties that make it quite valuable. ${ }^{16}$

This research was conducted in three different locations, and all locations are limestone processing areas in the work area of the Cipatat Health Center, West Bandung Regency. Cipatat is one of the areas in West Bandung which is the center of limestone processing. Limestone dust as a by-product can be seen clearly along the Rajamandala road. If processing activities are busy, sometimes limestone dust can reduce the visibility of workers in the company area. One of the three companies used as research locations has limestone dust exposure levels exceeding TLV.

Limestone dust that spreads outside the work environment area can endanger the health of workers but also has the potential to cause health problems in the surrounding communities of limestone processing companies. Companies based on laws and regulations must implement work safety and health efforts aimed at protecting the health and safety of workers as well as protecting the health of the community around the company

Table 2.

Frequency Distribution of Lung Function Capacity in Workers in the Limestone Processing Industry in Cipatat Health Center, West Bandung Regency

\begin{tabular}{ccc}
\hline Lung Function & \multicolumn{2}{c}{ Distribution } \\
\cline { 2 - 3 } Capacity Category & \multicolumn{2}{c}{} \\
\cline { 2 - 3 } & $\mathbf{N}$ & $\mathbf{\%}$ \\
\hline Normal & 18 & 43.8 \\
Abnormal & 14 & $\mathbf{1 0 0 . 0}$ \\
Total & $\mathbf{3 2}$ & \\
\hline
\end{tabular}

From table 2, distribution of Lung Function Capacity in Workers in the Limestone Processing Industry of the Cipatat District Health Center in West Bandung

The results of checking lung function capacity of 32 workers, showed 14 workers had impaired lung capacity (abnormal), while 18 other workers were declared normal. The capacity of lung function is the ability of the lungs to accommodate air when breathing. Decreased and increased lung function capacity has an impact on the health of workers.

Limestone dust has different sizes. Dust particles that enter the lungs will determine the location of the attachment or deposition of these particles. Dust that is between 5-10 microns will be held by the upper airway, while the central airway will hold those that are 3-5 microns. Dust particles that have a size between 1-3 microns will go straight into the alveoli surface. Dust that is less than 0.1 micron is too small, so it does not stick to the
Regency, it can be explained that almost half $(43.8 \%)$ workers in the limestone processing industry have abnormal lung function capacity.

surface of the alveoli or mucous membrane but because of the brown motion, the dust is moved in and out of the alveoli. ${ }^{17,18}$

According to Wulandari, Sertiani, and Y.D explained that the entry and exit of dust in the lungs could provide stimulation to the organ, wherein dust particles can stimulate the circular smooth muscle in the respiratory tract so that it can cause contraction of the respiratory tract narrowing, especially in the lungs. Dust particles that settle on the surface of the alveoli will stimulate the direction of macrophages in chronic conditions that can stimulate fibroblast cells found in the intersection tissue (guard tissue). If this condition is left for a long time without proper medical treatment, health problems can arise namely fibrosis. ${ }^{17}$ 
If dust is inhaled continuously and deposited in the alveoli, it can cause alveolar fibrosis. If the alveoli harden, it can cause the elasticity in accommodating decreased air volume. Simple confirms the decrease in lung elasticity in collecting air causes the ability to bind oxygen down and decreased lung function capacity. ${ }^{17}$ The longer the work continues to be left in environmental conditions with air polluted with limestone dust pollution, the more susceptible to impaired lung function capacity. ${ }^{19}$

Table 3.

Relationship of Limestone Dust Exposure to Lung Function Capacity

\begin{tabular}{ccccccccc}
\hline \multirow{2}{*}{$\begin{array}{c}\text { Limestone Dust } \\
\text { Exposure }\end{array}$} & \multicolumn{4}{c}{ Lung Function Capacity } & & \multirow{2}{*}{ Total } & \multirow{2}{*}{ Chi-Square (p-value) } \\
\cline { 2 - 6 } & \multicolumn{2}{c}{ Normal } & \multicolumn{2}{c}{ Abnormal } & & & \\
\cline { 2 - 6 } & $\mathbf{n}$ & $\mathbf{\%}$ & $\mathbf{n}$ & $\mathbf{\%}$ & $\mathbf{n}$ & $\mathbf{\%}$ & \\
\hline $\begin{array}{c}\text { Conformance } \\
\text { TLV }\end{array}$ & 2 & 50 & 2 & 50 & 4 & 100 & 1.000 \\
$\begin{array}{c}\text { Non-conformance } \\
\text { TLV }\end{array}$ & 16 & 57,1 & 12 & 42,9 & 28 & 100 & \\
\hline
\end{tabular}

Analysis of the relationship between limestone dust exposure and lung function capacity was analyzed by crosstabs using a

The results of the analysis of the Relationship of Limestone Dust Exposure to Lung Function Capacity of Workers in the Limestone Processing Industry of the Cipatat Health Center in West Bandung Regency found that the p-value $(1,000)>$ of the alpha value $(0.05)$ so that Ho was accepted. Thus there was no relationship between exposure to limestone dust with lung function capacity in workers in the Limestone Processing Industry.

The results of crosstabs showed that there were 2 workers exposed to limestone dust according to the threshold value experiencing impaired lung function capacity, and 2 workers who were exposed to limestone dust according to the threshold value did not experience impaired lung function capacity. Whereas workers exposed to limestone dust exceeding the 12 threshold value among those with impaired lung function, the remaining 16 workers did not experience impaired lung function or normal capacity.

\section{DISCUSSION}

Along the Cipatat Rajamandala road, West Bandung Regency, there are several limestone processing industries. Most of them chi-square statistical test with $95 \%$ confidence level (alpha $=0.05)$.

are located in the Cipatat Health Center area. Limestone is the primary raw material for making roofing, ceramics, cosmetics, animal feed, fertilizers, detergents, and is also used for steel smelting. The rise of the limestone processing industry in the area causes that along the road Rajamandala is filled with limestone dust, which is clearly visible and sometimes limits visibility.

According to Harirington, Limestone treatment processes generally include the breakdown of limestone, filling into the furnace, burning, taking or dismantling, casting with water, stirring, and packaging. Before it becomes powder, then the lime is burned first in the furnace for about 3 days, here the $\mathrm{CaCO}_{3}$ decomposition reaction will occur and release $\mathrm{CO}_{2}$ into the air at environmental. ${ }^{20.21}$

According to ${ }^{22}$ the limestone industry has polluted the air with dust and gases from the processing process. Dust and gases caused by the new lime treatment process are in the work environment; this will result in workers being exposed to lime and gas dust at different concentrations and sizes. The main effects of lime dust on workers are abnormal and chronic 
lung function disorders, disruption of physiological function, eye irritation, sensory irritation and accumulation of hazardous substances in the body.

Dust is solid particles that are caused by natural forces or mechanisms such as processing, crushing, softening, fastpacking, blasting, etc. of materials, both organic and inorganic materials, such as stone, wood, metal ore, charcoal, granules of substances and so on. ${ }^{23}$

The results showed the level of lime dust in the limestone processing industry in the area of Cipatat Health Center, West Bandung Regency, the majority $(66.7 \%)$ had a condition of dust content according to the Threshold Value.

Not all dust can cause a decrease in the capacity of lung function in the lung tissue, because it depends on the size of the dust. Dust measuring 5-10 microns will be retained by the upper airway, while those measuring 3-5 microns will be held in the middle of the airway. Particles measuring 1-3 microns will be placed directly on the surface of the tissue in the lungs. ${ }^{24}$

Size of Limestone Dust Threshold Value according to Permenakertrans No. 13 of 2011 is 3,000 $\mu \mathrm{g} / \mathrm{Nm} 3$ about Chemical Factor Threshold Limit Value in the air, with the size of limestone dust that can be seen by the ordinary eye that is $\mathbf{5}$ microns to less than $\mathbf{5 0}$ microns, and under 5 microns can be seen using a microscope. ${ }^{10}$

Conditions in the field at the time of the study showed the amount of white limestone dust that could be seen by ordinary eyes. Chalkdust can interfere with vision and breathing, can even make activities less comfortable.

It is known that limestone contains many chemical elements, which in high concentrations can endanger the health of workers. The most chemical elements from new lime are calcium oxide $(\mathrm{CaO})$, silicon dioxide $\left(\mathrm{SiO}_{2}\right)$, magnesium oxide $(\mathrm{MgO})$ and other elements. Workers exposed to limestone exceeding the threshold have the potential to experience impaired lung function capacity. ${ }^{20}$

The results showed that almost half (43.8\%) workers in the limestone processing industry in the Cipatat Health Center in the area of West Bandung Regency had abnormal lung function capacity.

The lung is an organ consisting mostly of bubbles (air bubbles/alveoli). This bubble consists of epithelial and endothelial cells. In this layer of air exchange occurs, oxygen enters the blood and carbon dioxide is released from the blood. ${ }^{25}$

Many factors affect lung capacity, including internal factors such as age, sex, nutritional status, and history of the disease. While external factors consist of smoking, work history, exercise habits and the use of personal protective equipment. ${ }^{26}$

Most workers in the limestone processing industry do not use personal protective masks, although the company has provided personal protective equipment such as masks, most of the workers in the limestone processing industry are reluctant to use the nose mask because they feel uncomfortable when working.

Personal protective equipment is quite effective in preventing lung function disorders in workers exposed to dust. Research ${ }^{27}$ explains that the use of PPE is associated with the occurrence of impaired lung function in lime workers. As many as $73.90 \%$ of workers who have a habit of using PPE do not experience pulmonary physiology.

Research ${ }^{17}$ explains that PPE provides a vital role in preventing the disruption of lung function capacity. PPE inhibits or minimizes dust exposure while working. According to ${ }^{17}$ shows that there is a relationship between the use of PPE to impair lung function. Workers who do not use PPE have a risk of impaired lung function 6 times higher than workers who use PPE. Therefore, workers are highly recommended to use PPE when working. Fabric masks with small pore sizes adjusted to the size of the dust can be used so that dust 
particles do not enter the respiratory tract. Then it can also use an air purifying respirator, this tool works as an air cleaner by filtering or absorbing dust particles before entering the respiratory tract. Other protective equipment that can be used is safety shoes, safety glasses and special clothing.

In addition to PPE, several other efforts can be carried out as controlling health risks from exposure to lime dust, including elimination control, consuming adequate drinking water as an effort to eliminate dust entering the digestive tract, drinking water is also beneficial to prevent dehydration. Using water spray, this is used to reduce the air that flies in the air so it does not enter the respiratory tract. Washing clothes, hands, and washing the body to be clean from exposure to nitrogen dioxide.

Substitution control can be done by replacing rest areas or providing rest areas that are free from exposure to lime dust, and replacing damaged production equipment so that the resulting pollution does not exceed the threshold value and endanger health. Isolation control can also be carried out by isolating the workplace, which causes an increase in the concentration of dust and toxic gases in the air by closing the dust spreaders.

Administrative control can be done by arranging work time, arranging rest hours, initial, periodic and special health checks on workers, conducting health promotion at work and installing some health information in order to increase workers' concern for health. Workers can also pay attention to personal hygiene and improve clean and healthy living behaviors such as not smoking, diligent exercise, and applying adequate sleep patterns.

Workers with unhealthy lifestyles such as smoking habits, can increase the risk of impaired lung function capacity. According to ${ }^{28}$ workers who smoke have more pulmonary physiology than those who do not smoke. Human lungs have elastic properties like a balloon, and they will expand when someone breathes in and deflates when someone exhales. Toxins from cigarette smoke can reduce the elasticity of the human lungs. Consequently, a person will develop chronic lung disease. Cigarette smoke is rich in carbon monoxide (CO), the nature of this substance which reactively forms carbon dioxide $\left(\mathrm{CO}_{2}\right)$ bonds by taking oxygen atoms from the blood $\left(\mathrm{HbO}_{2}\right)$. This condition causes blood circulation throughout the body to be disrupted, resulting in dampness in several respiratory and cardiovascular diseases.

Workers exposed to limestone have the potential to experience health problems such as impaired lung function capacity. ${ }^{29}$ According to the research that has been done, the results show that there is no relationship between the exposure to limestone dust to the lung function capacity in the limestone processing industry workers in the Cipatat Health Center, West Bandung Regency.

In the absence of a relationship between limestone dust exposure and lung function capacity, this could be due to other factors affecting lung function because dust exposure is not the only factor affecting lung function capacity. According to ${ }^{26}$ factors affecting lung function, capacity consists of internal and external factors. Internal factors consist of age, sex, disease history, and nutritional status, while external factors include smoking, exercise habits and work habits of personal protective masks at work.

The results of this study are in line with research conducted by ${ }^{27}$, that there is no relationship between exposure to lime dust with the pulmonary physiology status of workers. It was further explained that other factors could affect lung function, among the working periods and length of work per day.

This study contradicts the results of research conducted by $^{30}$ that there is a relationship between dust levels and lung function disorders in workers exposed to dust. This can occur because of differences in dust characteristics, dust particle size, and type of dust that can have a different impact on each worker. Moreover, personal factors such as age 
and sex are also expected to affect lung function disorders due to dust exposure.

According to ${ }^{31}$, the origin of air pollution can be explained by 3 (three) processes, namely attrition, vaporization, and combustion. Of the three processes above, combustion is a process that is very dominant in its ability to cause pollutants. The mechanism of dust pollutant entry into the worker's body through the air enters the upper airway, which consists of the oral cavity and nose, pharynx, larynx, trachea, bronchi and up to the lungs. Dust can also enter the digestive tract. Dust with a particle size of 5 to 30 microns that enters the body will settle to the upper respiratory tract, especially in the nasopharynx (nasal nose) and throat. Then the particles are swallowed with the lenders who will then be absorbed through the digestive tract. $^{32}$

This research shows that there are 2 workers exposed to limestone dust that does not overtake TLV but have abnormal lung function capacity. This can occur because the capacity of lung function is not only influenced by exposure to limestone dust. As stated by ${ }^{27}$ that pulmonary function can also be influenced by individual work habits, such as exercise habits. In addition to exercise habits, impaired lung function capacity can also be influenced by smoking, as stated by ${ }^{32}$ that smoking can affect pulmonary physiology.

A total of 16 workers exposed to dust with levels exceeding the threshold in this study showed that these workers have normal lung function capacity. Theoretically, it was conveyed that workers exposed to limestone dust exceeding TLV could experience lung function disorders. However, not so in this study, it can be caused by worker compliance with PPE usage and length of dust exposure to workers, as stated by ${ }^{33}$ that PPE is used to protect workers from exposure to limestone dust every day when working.

The threshold value is designed for workers who work for 8 hours per day, but if the worker works for less than 8 hours, it does not exceed the limit value of dust exposure to workers. Field conditions of workers work for 10 hours per day, meaning that exposure to dust exceeds the TLV for 8 hours is worsened by the length of working hours that exceeds regular working hours, according to the theory workers can experience impaired lung function capacities. Workers who do not experience impaired lung function can occur if workers apply a clean and healthy lifestyle and use personal protective equipment. In addition to the duration of exposure, the length of service can affect the worker's lung function capacity due to exposure to limestone dust. This is confirmed by the results of the study ${ }^{34}$ that $75 \%$ of workers with a work period of $>10$ years experience impaired pulmonary status.

Research by ${ }^{33}$ about the relationship between work duration and occupational dust exposure with the vital lung capacity of limestone processing workers in Sidorejo Ponjong Gunungkidul Yogyakarta concludes that the working period of workers exposed to limestone dust is related to vital lung capacity. Long or long periods of work carry a higher risk of disruption in the vital capacity of lung function compared to new years of service. This study also shows that there is no relationship between exposure to new lime dust and the vital lung capacity of workers.

The dust has different particle sizes. The size of these particles affects human health. According to the ${ }^{35}$, dust particles are formed from solid and liquid particles found in the air. Based on its size, dust is grouped into dust particles $\leq 10$ micrometers $\left(\mathrm{PM}_{10}\right)$ and dust particles $\leq 2.5$ micrometers $\left(\mathrm{PM}_{2.5}\right)$. The size of $\mathrm{PM}_{10}$ is about $1 / 7$ of the size of human hair or $1 / 9$ of the size of beach sand. ${ }^{28}$

Research on the effect of lime dust exposure on the lung function status of workers with the title "The description of lung function status of ammonium limestone milling industry workers in Tuban Regency" was conducted by 28 concluded that dust particles in the work environment can cause respiratory problems such as phlegm, coughing, phlegm coughing, 
and flu conditions. This study explains that most workers exposed to lime dust experience pulmonary physiology. Workers who experience pulmonary physiology are more dominant in the work environment area, having higher dust and temperature and lower humidity.

Companies are required to carry out work environment quality measurements periodically, based on Minister of Manpower, and Transmigration Number 5 of 2018 that monitoring environmental quality is carried out on 5 factors that have the potential to cause health problems and workplace accidents, namely monitoring of chemical, biological, psychosocial, ergonomics and physical environment. Included in physical factors are the level of environmental dust, noise, lighting, working environment temperature, vibration, and radiation exposure. ${ }^{36}$

In addition to measuring environmental quality, companies need to complete work safety equipment, such as PPE, as stipulated in ${ }^{1}$ concerning work safety. Health checks and organizing occupational health services.

Worker health is an essential asset in a company. Healthy workers can increase personal productivity as well as the company. Diseases such as impaired lung function capacity experienced by workers due to an unhealthy work environment can directly harm

\section{REFERENCES}

1. President of the Republic of Indonesia. Law Number 1 of 1970 on Occupational Safety. Jakarta: President of the Republic of Indonesia; 1970.

2. Tarwaka S. Manajeman dan Implementasi K3 di Tempat Kerja. II ed. Surakarta: Harapan Press Surakarta; 2004.

3. Sedarmayati. Sumber Daya Manusia dan Produktivitas Kerja. Bandung: CV. Mandar Maju; 2009.

4. Suma'mur P. Higiene Perusahaan dan Kesehatan Kerja. Jakarta: EGC; 1996.

5. Guyton AC, Hall JE. Fisiologi kedokteran. Terjemahan Irawati the company. The amount of maintenance costs is not small, if workers do not come to work due to illness, then the number of lost work hours increases and automatically reduces company productivity.

A successful company is a company that can guarantee that all workers are protected by health and safety. Consumer confidence in companies can increase if all aspects of OHS are applied. The number of work accidents is small even zero. If the incidence of occupational diseases is not found in a company, prospective customers will not think long to start cooperation with the company. This is the basis for the company to carry out all aspects of occupational health. Health inspection reports can be an essential document in the preparation of contracts and company profiles. Impaired lung function capacity that should occur can be minimized if all aspects of OSH are applied.

\section{CONCLUSION}

Based on the results of research and discussion that have been raised by the author in the previous chapter, conclusions: There is no relationship between limestone dust exposure and lung function capacity of workers in the Limestone Processing Industry in the Cipatat Health Center

Setiawan. Jakarta: EGC; 1997.

6. Mutmainnah RN, Setyani O, Nurjazulli. Perbedaan Fungsi Paru Pada Pekerja Berdasarkan Unit Kerja di Industri Tepung Tapioka Kecamatan Margoyoso Kabupaten Pati. J Kesehat Masy. 2019;7(1):404-11.

7. Kurth L, Doney B, Weinmann S. Occupational exposures and chronic obstructive pulmonary disease (COPD): Comparison Of A COPD-Specific Job Exposure Matrix And Expert- Evaluated Occupational Exposures. Occup Env Med. 2017;74(4):290-3. 
8. International Labour Organization (ILO). The Global Occupational Health Network. Geneva: Gohnet Newsletter; 2013.

9. Sucipto E. Hubungan Pemaparan Partikel Debu pada Pengolahan Batu Kapur Terhadap Penurunan Kapasitas Fungsi Paru. Thesis. Semarang: Faculty of Public Health, Universitas Diponegoro; 2007.

10. Pujiastuti W. Debu Sebagai Bahan Pencemar yang Membahayakan Kesehatan Kerja. Jakarta; 2002.

11. Department of Health Republic Indonesia. Report of Lung Health. Jakarta: Department of Health Republic Indonesia; 2003.

12. Prasetyo DR. Faktor-faktor yang Berhubungan dengan Kapasitas Vitas Paru pada Pekerja Bengkel Las di Pisangan Ciputat Tahun 2010. Undergraduate Thesis. Jakarta: Faculty of Medicine, UIN Syarif Hidayatullah; 2010.

13. Sugiyono. Metode Penelitian Kuantitatif Kualitatif dan R \& D. Bandung: Alfabeta; 2015.

14. Notoatmodjo S. Metodologi Penelitian Kesehatan. Jakarta: Rineka Cipta; 2012.

15. Noviyanti, Jasruddin, Sujiono EH. Karakteristik Kalsium Carbonat $(\mathrm{Ca}(\mathrm{CO} 3)$ dari Batu Kapur Kelurahan Tellu Limpoe Kecamatan Suppa. J Sains dan Pendidik Fis. 2015;2(11):169-72.

16. Subramani S, Fernández F, Santos AJ Dos, Río M del, López O. Effects of Moisture on Building Limestone. J An Edif. 2019;5(1):66-71.

17. Wulandari R, Sertiani O, Nikie AYD. Hubungan Masa Kerja Terhadap Gangguan Fungsi Paru Pada Petugas Penyapu Jalan di Protokol 3. 4 dan 6 Kota Semarang. J Kesehat Masy. 2015;3(3):797-806.

18. Wardhana WA. Dampak Pencemaran Lingkungan (Edisi Revisi). Yogyakarta: Penerbit Andi; 2004.

19. Simaela SL. Faktor-faktor yang Berhubungan dengan Kapasitas Maksimal Paru Pekerja Perusahaan Pemecah Batu pada PT. P di daerah Bogor Jawa Barat. Undergraduate Thesis. Semarang: Faculty of Public Health, Universitas Diponegoro; 2000.

20. Destriani SF. Pengaruh Paparan Debu Gamping Terhadap Kapasitas Vitas Paru pada Pekerja Tobong Gamping UD. Sidomulyo Desa Ngampel Kabupaten Blora. Unnes J Public Heal. 2013;2(4):18.

21. Harirington JM. Buku Saku Kesehatan Kerja. Jakarta: EGC; 2003. 36 p.

22. Bwalya D, Bratveit M, Moel BE. Chronic Respiratory Symptoms Among Workers at a Limestone Factory in Zambia. J Arch Env Occup Heal. 2011;66(1):24-32.

23. Suma'mur. Higene Perusahaan dan Kesehatan Kerja. Jakarta: Gunung Agung; 2009.

24. Sugandi I. Hubungan Antar Paparan Debu Padi Dengan Kapasitas Fungsi Paru Tenaga Kerja Industri Penggillingan Padi di Desa Balegede Kecamatan Naringgul Kabupaten Cianjur. Undergraduate Thesis. Bandung: Public Health Study Program, STIKes Bhakti Kencana Bandung; 2013.

25. Syaifuddin. Anatomi Fisiologi untuk Siswa Perawat. Jakarta: EGC; 1997.

26. Antaruddin. Pengaruh Debu Padi pada faal paru pekerja kilang padi yang merokok dan tidak merokok. Undergraduate Thesis. Medan: Faculty of Medicine, Universitas Sumatera Utara; 2003.

27. Armaeni ED, Widajati N. Hubungan Paparan Debu Kapur dengan Status Faal Paru Pada Pekerja Gamping. Indones J Occup Saf Heal. 2016;5(1):61-70.

28. Sudrajat M, Azizah R. The Description of Lung Function Status Among Limestone Milling Industry Workers in Tuban Regency. J Kesehat Lingkung. 2016;8(2):238-47.

29. Akili RH, Kolibu F, Tucunan AC. Kejadian Penyakit Infeksi Saluran Pernapasan Akut pada Pekerja Tambang Kapur. J Kesehat Masy. 2017;11(1):41-5.

30. Noor RA, Djajakusli R, Masyita M. Faktor yang Mempengaruhi Kejadian Gangguan Fungsi Paru pada Pekerjaan Pengangkut Semen di Gudang Penyimpanan Semen Pelabuhan Malandung Kota Tarakan, Kalimantan Timur. J Kesehat Masy UNHAS. 2012;2(1):1-8.

31. Mukono. Pencemaran Udara dan Pengaruhnya Terhadap Gangguan Saluran Pernafasan. Surabaya: Airlangga University Press; 1997. 
32. Sholihah M, Tualeka AR. Studi Faal Paru dan Kebiasaan Merokok Pada Pekerja yang Terpapar Debu di Perusahaan Konstruksi Surabaya. Indones J Occup Saf Heal. 2015;4(1):1-10.

33. Astuti D, Sofiana L. Hubungan antara lama kerja dan paparan debu lingkungan kerja dengan kapasitas vital paru pekerja pengolah batu kapur di Sidorejo Ponjong Gunungkidul Yogyakarta. J Ber Kedokt Masy UGM. 2019;35(4):1-11.

34. Ardam KAY. Hubungan Paparan Debu dan Lama Paparan dengan Gangguan Faal Paru Pekerja Overhaul Power Plant. Indones J Occup Saf Heal.
2015;4(2):155-66.

35. Environmental Protection Agency. U.S Environmental Protection Agency Offi ce of Air Quality Planning and Standards Emissions, Monitoring, and Analysis Division. The Particle Pollution Report. North Carolina: Environmental Protection Agency; 2004.

36. Minister of Manpower and Transmigration. Number 5 Year 2018. Occupational Safety and Health Work Environment. Jakarta: Minister of Manpower and Transmigration; 2018. 